\title{
Blue Flag Beaches-Bathers at Risk for Thalassogenic Diseases
}

\author{
Edda Weimann, MD, MPH \\ School of Public Health and Family Medicine, Health Sciences Faculty, University of \\ Cape Town, Anzio Road, Observatory 7925, Cape Town, South Africa
}

Tel: 27-21-689-4549_E-mail: prof.dr.weimann@gmail.com/edda.weimann@uct.ac.za

Received: December 21, 2013 Accepted: February 6, 2013 Published: June 5, 2014

doi:10.5296/jee.v5i1.5773ＵRL: http://dx.doi.org/10.5296/jee.v5i1.5773

\begin{abstract}
If beaches and water are polluted by wastewater, bathers are at risk for thalassogenic diseases such as diarrhea, skin infection, respiratory tract infection and hepatitis. The coastal water around the Cape Peninsula in South Africa is affected by polluted rivers that flow into the ocean, major shipping routes and wastewater outlets of human settlements. With high tide the water from offshore is brought onto the beach area and towards the coastline.

Results: Sea water was collected from the eco-labeled Blue Flag beach, Clifton, Cape Town, during peak season in February and March 2013 at high tide to culture E. coli. The tested water quality was between $10^{4}$ and $10^{6}$, indicating that Clifton Blue Flag beach is affected by waste water. Foam and yellowish coloring of sand was associated with elevated E. coli counts. Data of water analysis are only displayed at Blue Flag beaches with a delay of two to three weeks.

Conclusions: Swimming on a Blue Flag beach does not exclude time limited waste water pollution. Regular external and independent quality surveillance of Blue Flag beaches is mandatory, besides more rapid measurement and timely display of water analysis. Especially infants and people with HIV and/or Tb infections are at risk for health hazards as they are immune compromised. Swimmers should be aware of the risk they are taking when bathing in polluted water and know the signs of waste water pollution. Due to the high burden of HIV and $\mathrm{Tb}$ infection, further large scale studies are needed to evaluate the health effects for bathers besides the economic impact of improved wastewater treatment in South Africa.
\end{abstract}

Keywords: Water pollution, Blue Flag beach, HIV, Tb, Thalassogenic diseases, Sushi 


\section{Introduction}

Worldwide a huge proportion of people live in cities along the coastline. They are causing daily wastewater discharge with little or no treatment into the marine coastal waters (Wade et al., 2006). Sewage polluted water contains millions of infectious dosages of pathogenic microorganism (Shuval, 2003) such as E. coli, Enterococcus, EHEC, Cryptosporidium, Norwalk like virus and Leptospira (E. M. Cooke, 1974, Fleisher JM, Jones F, Kay D, Stanwell-Smith R, Wyer M 1993, C. M. Ferguson, B.G. Coote, N. Ashbolt 1996, D.W. Griffin, K.A. Donaldson, J. H. Paul 2003). A study, initiated by the WHO estimated the global burden of thalassogenic diseases (Shuval, 2003): 120 million cases of gastrointestinal diseases, over 50 million severe respiratory and roughly four million cases of infectious diseases such as Hepatitis A and E, resulting in 40.000 deaths and 40.000 cases of chronic liver diseases were calculated. Above and beyond seafood and shellfish are hosted along the coastline. Often it is eaten raw as Sushi or lightly steamed. The worldwide costs of wastewater pollution of the sea is estimated to be about three million disability adjusted life years (Suhval H., 2003). An additional risk is related to the transfer of antibiotic resistant bacteria in sewage water (Kümmerer, 2004; Martins da Costa, Vaz-Pires, \& Bernardo, 2006), (Schwartz, Kohnen, Jansen, \& Obst, 2003).

South Africa with its over $6.000 \mathrm{~km}$ long and picturesque coastline attracts many bathers and surfers worldwide. Regular water surveys and recommendation for bathers are in existance for the European Union (EUA-Report 2013, Prieto 2001) and the United States (Lee SH, Levy DA, Craun GF, Beach MJ, 2002; U.S. Environmental Protection Agency, 2004), but only few data are publised regarding water quality and health hazards in South Africa (City of Cape Town, 2012; Lusher, 1984). Swimmer and surfer swallow significant amounts of water. Adult swimmers are prone to ingest $10-100 \mathrm{ml}$ seawater, while children probably ingest larger quantities of water. Especially young children, grown ups and people infected with HIV and Tb (Thea DM, St Louis ME, Atido U, Kanjinga K 1993) are at risk to suffer health hazards by ingesting sewage polluted water (Fleisher, JM, Jones, F, Kay, D, Stanwell-Smith, R, Wyer, M, Morano, 1993). South Africa is the country with the highest HIV burden worldwide (UNAIDS, 2012). Although the HIV epidemic has stabilised over the last four years due to the availibility of antiretroviral treatment, the number of people living with HIV is 5,6 million (UNAIDS 2012) associated with a high amount of an immocompromised population. They need to be informed about the risk and health hazards of thalssogenic diseases such as diarrhea, skin infection, respiratory tract infection, and hepatitis (Griffin, D.W., Donaldson, K.A . Paul, 2003), (Lee SH, Levy DA, Craun GF, Beach MJ, 2002).

36 beaches in South Africa have been awarded a Blue Flag status for excellent bathing quality (City of Cape Town, 2013). The Blue Flag is a highly respected and internationally recognized eco-label, although beach goers often do not know the underlying standards of a Blue Flag beach (Mc Kenna J, Williams, A.T., 2011). The label is awarded to beaches on an annual basis that meet criteria for water quality, environmental education, environmental management, safety and services (Blue Flag, 2013). No industrial waste water or sewage related discharges should affect the beach area (City of Cape Town, 2013). As water pollution can also result from bathers, the beach must be kept clean, no dogs are allowed and small 
particles such as cigarette butts must be removed on a regular basis. Analysis of water quality should be performed every two to four weeks. The Blue Flag Beaches in South Africa must comply with the water quality standards for E. coli 100/100 ml and for Enterococci 50/100 ml (City of Cape Town, 2012). European and US American standards for E. coli are set by $10^{2} / 100 \mathrm{ml}$ and below (EU, 2009; U.S. Environmental Protection Agency, 2004). A large amount of the South African population is immune compromised due to the high HIV/AIDS and $\mathrm{Tb}$ infection rate and is therefore more vulnerable to E. coli and Enterococcus infections.

South Africa leads its waste water into the ocean offshore which only one treatment, which means that it has only been filtered. E. coli is not removed with this treatment and only the waste particles are filtered out. On top, the wetlands and rivers in South Africa are heavily polluted (City of Cape Town, 2012). The phosphate levels of the rivers on the Cape Peninsula such as Sout River near Melkbosstrand, Wildevoelvlei, Kuils River (Mosselbank) and River Salt catchment are generally in the extreme hypertrophic range ("unacceptable") with respect to phosphorus enrichment (Water Services City of Cape, 2012). The sources of nutrient enrichment range from sewage overflows, treated effluents and urban catchment runoff. The rivers flow into the sea with polluted waste water. The current status of South African rivers needs improvement including the removal or avoidance of phosphorus enrichment (DeGeorges, Goreau, \& Reilly, 2010).

Sewage pipes are led into the ocean $1.7 \mathrm{~km}$ offshore of Camps Bay beach and the water flows up the coastline of South Africa towards the Clifton beach. With high tide water from offshore is brought onto the beach area and coastline. Schippmann et al have illustrated a 3D ocean model that sewage treatment and wind conditions can cause fecal pollution up to 20 km downstream (Schippmann B, Schernewski G, 2013).

Escherichia coli or E-coli is a gram-negative bacterium and is typically rod-shaped. It is a growing body which can survive for extended periods of time out of its host. It is therefore suitable for tests and laboratory setting. E-coli is a germ which is found in the intestine of humans and animals (Cooke, 1974) A typical red coloring of E-coli bacteria appears when it is cultured. E. coli is recognised internationally as a marker for fecal water pollution (Wade et al. 2006, Geldreich 1970).

We performed a survey to elucidate the water quality and management on a Blue Flag beach in Cape Town. The results are discussed in the light of the high burden of HIV and Tuberculosis (Tb) with an immune compromised population and the current used standards for Blue Flag beaches in South Africa.

\section{Research Methods}

A prospective case study was conducted. Clifton, 4th beach was specifically selected as it is one of the most popular beaches on the Cape Peninsula and can be easily accessed. It is located in the central area of Cape Town and is well known as a Blue Flag Beach. In comparison to other beaches that only offer one month of Blue Flag status, the Blue Flag season ran from 1 December 2012 to 31 March 2013. Clifton beach lies in proximity to the main shipping route, several wastewater pipes are led offshore into the ocean and discharges 
from wastewater plants in Sea Point and rivers flow into the sea.

Water sample collection and analysis. Water was collected from Blue Flag beach, Clifton from the 14 February to the 9 March 2013 at high tide using six tests to culture E. coli. This was done more frequently as Blue Flag Standards, which require testing the water quality every 2 - 4 weeks. Each time a photo documentation of the beach and water was performed.. Micro slides (Precision Microslides ${ }^{\circledR}$ ) were held in the water mixture for several seconds and then put back into its casing. It is recommendable to take the water sample about $15-20 \mathrm{~cm}$ beyond the surface. The test kit was bred with the casing at a temperature between $33^{\circ}-35^{\circ}$ for at least 48 hours. It is a typical sign of E. coli when red marks appear.

\section{Results}

In $83 \%$ E. coli counts exceeded $10^{2}$. Values over $10^{4}$ were associated with signs of wastewater pollution, such as yellowish foam on the water (Picture 1) and yellowish colored sand (Table 1).
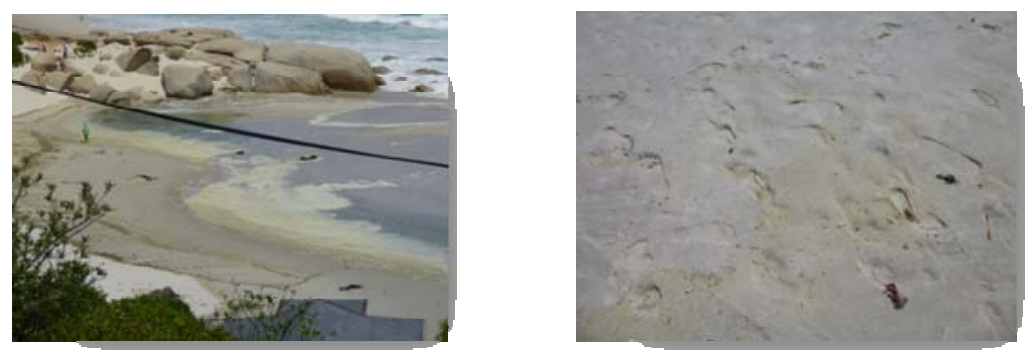

Picture 1. Foam and sand coloring on Clifton, Blue Flag Beach

At the time when the tests were taken, various issues of the Blue Flag statute were not considered: dogs were on the beach despite prohibition signs; data of water analysis were not displayed on the Blue Flag board or the board was not present.

Table 1. Days and times of water collection and results

\begin{tabular}{|l|l|l|l|}
\hline Date & $\begin{array}{l}\text { Time water } \\
\text { collection } \\
\text { (High tide) }\end{array}$ & Description of sea water and beach & $\begin{array}{l}\text { Amount } \\
\text { E. coli }\end{array}$ \\
\hline $\begin{array}{l}\text { Thursday } \\
\text { 14/02/2013 }\end{array}$ & $6: 30$ p.m. & $\begin{array}{l}\text { Foam on the water in the distance of 800-1000 m offshore, } \\
\text { no Blue Flag board on beach, Blue Flag hoisted }\end{array}$ & $10^{3}$ \\
\hline $\begin{array}{l}\text { Wednesday } \\
\text { 20/02/2013 }\end{array}$ & $1: 00$ p.m. & $\begin{array}{l}\text { Heavy foam on water, Blue Flag board present, but without } \\
\text { data, Blue Flag hoisted }\end{array}$ & $10^{5}-10^{6}$ \\
\hline $\begin{array}{l}\text { Tuesday } \\
\text { 26/02/2013 }\end{array}$ & $4: 30$ p.m. & $\begin{array}{l}\text { Foam on water, sewage station on the beach under repair, } \\
\text { board without data, Blue Flag hoisted }\end{array}$ & $10^{4}$ \\
\hline $\begin{array}{l}\text { Saturday } \\
\text { 02/03/2013 }\end{array}$ & $6: 30$ p.m. & Foam on water, no results on board, Blue Flag hoisted & $10^{4}$ \\
\hline Wednesday & $11: 30$ a.m. & Foam on water, no results on board, Blue Flag hoisted & $10^{5}$ \\
\hline
\end{tabular}




\begin{tabular}{|l|l|l|l|}
\hline $06 / 03 / 2013$ & & & \\
\hline $\begin{array}{l}\text { Saturday } \\
09 / 03 / 2013\end{array}$ & $1: 30$ p.m. & $\begin{array}{l}\text { Water looks fine, no foam, Blue Flag hoisted, results on the } \\
\text { board are finally filled in for the last months }\end{array}$ & $10^{2}$ \\
\hline
\end{tabular}

\section{Discussion}

Although Clifton Blue Flag beach is awarded a Blue Flag Beach, there are times when the coastal water of the bathing area is affected by wastewater. This emerges often after storms and heavy rains as overflows are washed into the sea (Van Donsel, Geldreich, \& Clarke, 1967).

During our study only one time the E. coli content was $10^{2}$. Various countries suggest the closing of beaches and taking of actions when the E.coli content exceeds 235/100 ml (U.S. Environmental Protection Agency, 2004). There is an ongoing debate to recommend lower limits for E. coli for recreational bathing areas (Lévesque \& Gauvin, 2007) as each individual reacts differently and an infection curve increases in relation to the amount of E. coli (Teunis, Takumi, \& Shinagawa, 2004; Wiedenmann et al., 2006). Bathers exposed to higher concentration of total coliform bacteria showed an significant increase in the risk of aquiring symptoms than non-bathers (Lévesque \& Gauvin, 2007; Prieto, 2001).

Table 2 displays how much wastewater is lead into the Southern African Indian Ocean (Annual Report 2012).

Table 2. Estimated volume of municipal wastewater discharge into the Southern Indian Ocean

\begin{tabular}{|l|r|}
\hline Country & $\begin{array}{l}\text { Estimated volume of } \\
\text { municipal wastewater } \\
\left(\mathbf{m}^{\mathbf{3}} / \mathbf{d a y}\right)\end{array}$ \\
\hline Comoros & 168,000 \\
\hline Kenya & 145,500 \\
\hline Mauritius & 173,500 \\
\hline Mozambique & 29,149 \\
\hline Seychelles & 10,372 \\
\hline South Africa & $\mathbf{2 5 5 , 0 0 0}$ \\
\hline Tanzania & 37,912 \\
\hline
\end{tabular}

Prieto et al (Prieto, 2001) underlined that the risk of health problems associated with bathing is related to the microbiological quality of the water. The researchers have pointed out that different susceptibility of the citizens of each country must be taken into account when analyzing the risk of coastal water pollution. Due to the high burden of HIV/AIDS and Tb special precautions should be taken in South Africa. Rapid changes in water quality occur due to current changes on the currents and wind directions (Schippmann B, Schernewski G, 2013). Hence the monitoring of the beaches and especially of Blue Flag beaches should be mandatory. Water analysis should be done more frequently than only every two to four weeks, especially in areas where are sewage pipes are led close-by into the ocean. 


\section{Conclusions}

Even a beach is awarded a Blue Flag beach, adults, children and especially immune compromised people are at risk for a thalassogenic disease when they bath in sewage polluted water. There are several managerial points of the Blue Flag beach in Clifton that need to be taken care of: Dogs are present on the beach despite well visible prohibition signs. Most of the time when our survey took place no water quality data were displayed, although the Blue Flag was hoisted. When data are displayed, they are delayed in time. The US Environmental Protection Agency (2004) recommends a 24 hour method to use for water testing at recreational bathing sites to minimize the time between sample collection and swimmer exposure. Alternatively a rapid measurement that can easily be performed on site might be recommendable. Otherwise, it is more reliable to look out for obvious signs of waste water pollution.

Up to now the burden of thalassogenic diseases in South Africa is not examined - neither for Blue Flag beaches nor for other beaches. Large scale public health studies with the undertaking of beachgoers and bathers health surveys are needed to estimate the thallosogenic burden of diseases in South Africa and the economic impact of improved wastewater treatment.

\section{References}

Blue Flag. (2013). Blue Flag Programme: Eco-label for beaches and marinas. Retrieved September 8, 2013, from http://www.blueflag.org

City of Cape Town. (2012). River Management: Inland and Coastal Water Quality Committee Annual Report 2011. Retrieved August 30, 2013, from http://www.capetown.gov.za

City of Cape Town. (2013). Blue Flag Programme: Blue Flag beaches and marinas are best. Retrieved December 3, 2013, from http://www.capetown.gov.za/en/EnvironmentalResourceManagement/publications/Document s/CCT_Blue_Flag_Beaches_e-booklet_2013-01-29.pdf

Cooke, E. M. (1974). Escherichia coli and man (p. 96). Retrieved from http://www.cabdirect.org/abstracts/19742704379.html;jsessionid=0D3FCF364E983E8268DA B6A487C3FCD8

DeGeorges, A., Goreau, T. J., \& Reilly, B. (2010). Land-Sourced Pollution with an Emphasis on Domestic Sewage: Lessons from the Caribbean and Implications for Coastal Development on Indian Ocean and Pacific Coral Reefs. Sustainability, 2(9), 2919-2949. doi:10.3390/su2092919

EU. (2009). EU Bathing Water Quality Directive. Retrieved December 3, 2013, from http://ec.europa.eu/environment/water/water-bathing/pdf/profiles_dec_2009.pdf

EUA-Report. (2013). Bathing quality in Europe 2012 Report. Retrieved August 30, 2013, from www.europa.eu

Ferguson, C. M., Coote, B. G., Ashbolt, N., \& Stevenson, I. M. (1996). Relationships between 
indicators, pathogens and water quality in an estuarine system. Water Res, 30(9), 2045-2054.

Fleisher, JM, Jones, F, Kay, D, Stanwell-Smith, R, Wyer, M, \& Morano, R. (1993). Water and Non-Water-Related Risk Factors for Gastroenteritis among Bathers Exposed to Sewage-Contaminated Marine Waters. International Journal of Epidemiology, 22(4), 698-708.

Geldreich, E. E. (1970). Applying bacteriological parameters to recreational water quality. $J$ American Water Works Association, 62(2), 113-120.

Griffin, D. W., Donaldson, K. A . Paul, R. J. H. (2003). Pathogenic Human Viruses in coastal water. Clin Microbiol Rev, 16(1), 129-143.

Kümmerer, K. (2004). Resistance in the environment. The Journal of antimicrobial chemotherapy, 54(2), 311-20. http://dx.doi.org/10.1093/jac/dkh325

Lee SH, Levy DA, Craun GF, Beach MJ, C. R. (2002). Surveillance for waterborne-disease outbreaks--United States, 1999-2000. MMWR Surveill Summ, 22(51 8)), 1-47.

Lusher, J. (1984). Water quality criteria for the South African Coastal Zone. Foundation for Research Development, Council for Scientific and Industrial Research. Retrieved from ISBN 0798832541

Lévesque, B., \& Gauvin, D. (2007). Microbiological guideline values for recreational bathing in Canada: Time for change? The Canadian journal of infectious diseases \& medical microbiology = Journal canadien des maladies infectieuses et de la microbiologie médicale / AMMI Canada, 18(2), 153-7. Retrieved from http://www.pubmedcentral.nih.gov/articlerender.fcgi?artid=2533533\&tool=pmcentrez\&rende rtype=abstract

Martins da Costa, P., Vaz-Pires, P., \& Bernardo, F. (2006). Antimicrobial resistance in Enterococcus spp. isolated in inflow, effluent and sludge from municipal sewage water treatment plants. Water Res, 40(8), 1735-1740. doi:http://dx.doi.org/10.1016/j.watres.2006.02.025.

Mc Kenna J, Williams, A. T., C. J. A. G. (2011). Blue Flag or Red Herring: Do beach awards encourage the public to visit beaches? Tourism Management, 32(3), 576-588.

Prieto, M. (2001). Recreation in coastal water: health risks associated with bathing in sea. $J$ Edimemiology Community Health, 55, 442-447.

Schippmann, B., \& Schernewski, G. G. U. (2013). Escherichia coli pollution in a Baltic Sea lagoon: A model-based source and spatial risk assessment. International Journal of Hygiene and Environmental Health, 216(4), 408-420.

Schwartz, T., Kohnen, W., Jansen, B., \& Obst, U. (2003). Detection of antibiotic-resistant bacteria and their resistance genes in wastewater, surface water, and drinking water biofilms. FEMS microbiology ecology, 43(3), 325-35. doi:10.1111/j.1574-6941.2003.tb01073.x

Shuval, H. (2003). Estimating the global burden of thalassogenic diseases: human infectious 
diseases caused by wastewater pollution of the marine environment. Journal of water and health, 1(2), 53-64. Retrieved from http://www.ncbi.nlm.nih.gov/pubmed/15382734

Suhval H. (2003). Estimating the global burden of thalassogenic diseases: human infectious diseases caused by wastewater pollution of the marine environment. $J$ Water Health, 2, 53-58.

Teunis, P., Takumi, K., \& Shinagawa, K. (2004). Dose Response for Infection by Escherichia coli O157:H7 from Outbreak Data. Risk Analysis, 24(2), 401-407.

U.S. Environmental Protection Agency. (2004). Nationwide Bacteria Standard protect swimmers at beaches. from http://water.epa.gov/lawsregs/lawsguidance/beachrules/bacteria-rule-final-fs.cfm

UNAIDS. (2012). UNAIDS. Retrieved September 2, 2013, from http:// www.UNAIDS.org

Van Donsel, D. J., Geldreich, E. E., \& Clarke, N. A. (1967). Seasonal Variations in Survival of Indicator Bacteria in Soil and Their Contribution to Storm-water Pollution. Applied and Environmental Microbiology, 15(6), 1362-1370.

Wade, T. J., Calderon, R. L., Sams, E., Beach, M., Brenner, K. P., Williams, A. H., \& Dufour, A. P. (2006). Rapidly Measured Indicators of Recreational Water Quality Are Predictive of Swimming-Associated Gastrointestinal Illness. Environmental Health Perspectives, 114(1), 24-28. http://dx.doi.org/10.1289/ehp.8273

Water Services City of Cape. (2012). Water services development plan for City of Cape Town 2008-2013. Retrieved August 30, 2013, http://dx.doi.org/ www.capetown.gov.za

Wiedenmann, A., Krüger, P., Dietz, K., López-Pila, J. M., Szewzyk, R., \& Botzenhart, K. (2006). A Randomized Controlled Trial Assessing Infectious Disease Risks from Bathing in Fresh Recreational Waters in Relation to the Concentration of Escherichia coli, Intestinal Enterococci, Clostridium perfringens, and Somatic Coliphages. Environmental Health Perspectives, 114(2), 228-236. http://dx.doi.org/10.1289/ehp.8115

\section{Copyright Disclaimer}

Copyright for this article is retained by the author(s), with first publication rights granted to the journal.

This is an open-access article distributed under the terms and conditions of the Creative Commons Attribution license (http://creativecommons.org/licenses/by/3.0/). 